\title{
Elimination of Viral Hepatitis and an Update on Blood Safety
} Technology

\author{
Marijn Thijssen, ${ }^{1}$ Marc Van Ranst, ${ }^{1}$ and Mahmoud Reza Pourkarim ${ }^{1,2,}$ \\ ${ }^{1}$ KU Leuven, Department of Microbiology and Immunology, Laboratory of Clinical and Epidemiological Virology, 3000, Leuven, Belgium \\ ${ }^{2}$ Blood Transfusion Research Centre, High Institute for Research and Education in Transfusion Medicine, Hemmat Exp. Way, 14665-1157, Tehran, Iran \\ "Corresponding author: Mahmoud Reza Pourkarim, Laboratory of Clinical and Epidemiological Virology, Rega Institute for Medical Research, Department of Microbiology \\ and Immunology, University of KULeuven, Herestraat 49, Postbus 1040, Leuven, Belgium. Tel: +32-16332145, Fax: +32-16321153, E-mail: mahmoudreza.pourkarim@kuleuven.be \\ Received 2018 January 22; Accepted 2018 February 03.
}

Keywords: HTS, NGS, Blood Safety, Hepatitis

\section{History of Viral Hepatitis and Blood Safety}

Viral hepatitis is a major public health problem. It is estimated that globally 350 - 400 and 140 - 170 million people are carrier of the hepatitis $B$ and hepatitis $C$ virus, respectively (1), which both account for 1.4 million deaths per year (2). The history of blood safety and blood screening has been closely related with the discovery of viral hepatitis. Hepatitis B virus (HBV) was identified in human blood (3) in the late 1960s and shortly after its discovery, related blood screening assays were introduced (4). This close association between blood safety and viral hepatitis got even stronger with the identification of the hepatitis C virus (HCV) in 1983 as a blood borne hepatotropic pathogen (5). The implementation of rigorous policies in blood donor selection and screening techniques, such as enzyme immunoassays (EIA) and nucleic acid amplification tests (NAT), have steadily decreased the risk of transmitting hepatitis viruses. Still, the majority of post transfusion infections are attributed to these pathogens (6-8). In addition, there is no universal method available to inactivate non-enveloped human hepatitis viruses like HAV and HEV in different blood derived-products $(9,10)$. Since a considerable number of transfused patients is immunocompromised and more vulnerable to these pathogens, viral hepatitis poses a significant threat to blood safety from a public health perspective (11). Moreover, mass migration, urbanization, human mobility and contact, increasing animal trades, and vector expansion due to climate change have allowed infectious agents, including hepatitis viruses (reservoirs), to pass the traditional endemic boundaries and disperse globally (11). Furthermore, in war-affected and unsafe geographical regions access to proper health services, like blood screening or healthy drink water, is restricted and might fuel a possible viral hepatitis outbreak
$(12,13)$. All these factors are crucial hurdles to the global elimination program of viral hepatitis by 2030 adopted by the world health assembly in 2016 (14). In this ambitious program, blood safety has been assigned as one of the key interventions, which demands the implementation of a new set of update methods and techniques in the surveillance of hepatitis causing viruses.

\section{What Is Our Expectation?}

Conventional techniques used in blood screening have several limitations. New methodologies should solve the bottlenecks of traditional methods and have a wide application potential. For instance, new assays should be sensitive enough to reduce the 'window period' of pathogens and favor the detection of blood borne viruses shortly after exposure and entering the blood stream (15). Also, new methods should allow the identification of viruses or viral components present in low amounts in the blood or blood derived products. This would be a crucial aspect, since the infectious dose of $\mathrm{HBV}$ is only 10 copy numbers per $\mathrm{ml}$ (16). Innovative screening methods should also be able to detect different variants or quasispecies of viruses (like HBV) that are capable of escaping from diagnostic tests, vaccine, or therapeutic measures. In this way, it is supposed that these assays efficiently detect all genotype/subgenotypes of hepatitis viruses $(17,18)$. Moreover, detecting viruses causing hepatitis in different clinical manifestations like the viremic phase, inactive or active chronicity, overt or occult infection, and intra or extracellular phase of viral life cycles could be a significant improvement of new methods compared to traditional assays. Furthermore, implementing novel methodologies should augment blood safety by 
identifying unknown infectious agents that may have hepatotropic impacts (11).

After a long period of using different generations of enzyme-linked immunosorbent assays (ELISAs) in blood screening units, NAT improved blood safety screening and partially addressed the abovementioned characteristics $(19,20)$. However, before reaching an optimized technique for screening practice, a difficult journey was still lying ahead. Fortunately, during the last decade with the development of high-throughput sequencing (HTS), and more specifically next generation sequencing (NGS), the required features have been assembled in a single platform. This promising approach is paving a new path for improving clinical diagnostics and blood safety.

By means of HTS, scientists have succeeded in characterizing microbial communities present in different biological samples. In contrast with conventional assays, this non-targeted approach provides access to all nucleic acids present in clinical specimens, like human blood, urine, stool, etc. The identification of unexpected infectious agents, for example in illnesses with unknown etiology, or the detection of novel variants of known viruses have marked the huge potential of this technique in the clinical diagnostic setting. This technique can rapidly sequence all viral nucleic acids (DNA and RNA), catalog the viral genes, and monitor viral populations as well as their diversity in blood. The collection of these viral populations is also known as the human virome. The strength of this method has convinced the national institute of health (NIH) to establish a task force of the heart, lung, and blood institute that prioritized human virome studies $(11,21)$.

Consequently, HTS has now been adopted as a useful strategy to identify and characterize known and unknown viruses in the blood virome, which could potentially compromise blood transfusion safety (22). By employing this innovative technology, several emerging pathogens have been identified (11). However, it is estimated that more than 320,000 undiscovered mammalian viruses, with the potential of being blood-transmissible, still need to be discovered (23).

\section{New Methodology and New Challenges}

New technologies often come with some drawbacks or pitfalls, and HTS is no exception. HTS is a non-targeted and random amplification based-approach. For example, the detection of hepatitis causing viruses in cases of low copy numbers (in non-viremic phase of chronicity) is highly challenging due to a considerable amount of host and environmental nucleic acids. However, viral nucleic acids enrichment techniques such as ultracentrifugation, filtration, and nuclease treatment have proven to be helpful strategies. Also, increasing sequencing depth could successfully reduce host background interference and maximize viral nucleic acid detection $(24,25)$. Regarding these pretreatments, VirCapSeq-VERT and Illumina platforms, among the available platforms of HTS, seem to provide enough sensitivity to detect low viral copy numbers in human plasma/serum samples (26). Due to high sensitivity and non-specificity of HTS, biological contamination with environmental nucleic acids can occur in the different steps of sample preparation and library construction. However, various strategies can be addressed to reduce the influence of contaminating agents, such as the use of negative controls during the different stages of sample processing (27).

\section{Current Achievements}

Day by day, more evidence supports the high potential of HTS in the field of blood safety. Identification and characterization of all viral communities present in the blood is an intriguing accomplishment of HTS. This challenging approach plays a crucial role in surveillance and detection of viruses that threaten the health of blood recipients. For example, in recent studies, HTS is frequently used to evaluate the safety of blood-derived components, like fresh pools of frozen plasma (FFP), red blood cell (RBC) units (28), and individual blood donors (29). Also, the use of HTS in human plasma virome studies of blood recipients has led to the discovery of a novel type of human pegivirus (HPgV) (formerly known as GB virus C, (GBV-C)) that shares some viral features with $\operatorname{HCV}(30,31)$. Moreover, this method was employed to identify novel rhabdoviruses in human blood (32). In other instances, HTS has successfully fulfilled a key role in the discovery of novel blood borne viruses such as the Giant Blood Marseille (GBM) virus in healthy blood donors and multiple transfused patients (33) and the Gemycircular virus (GemyCic) in HIV positive blood donors (34). Finally, this technology provides an opportunity to characterize the diversity of quasispecies of HBV and HCV in blood at different clinical complications as well (35-38).

\section{Conclusion}

The elimination of viral hepatitis is achievable when the most updated strategies and tools will be applied in blood safety. HTS, as the most recent technology, is a promising and suitable tool in viral surveillance and screening of blood products for blood borne pathogens such as hepatitis viruses. Beyond viral surveillance and discovery, HTS is enabling researchers in creating a clear image of the genome diversities of hepatitis virus in carriers, 
especially in high prevalent regions. Implementing this technique in the blood safety setting would be a great opportunity to establish state-of-the-art preventive measures and to tackle global viral hepatitis burden in the near future.

\section{Acknowledgments}

Marijn Thijssen is a SB PhD fellow at "Fonds voor Wetenschappelijk Onderzoek (FWO) Vlaanderen" of Belgium. Mahmoud Reza Pourkarim (MRP) is supported by a postdoctoral grant from the "Fonds voor Wetenschappelijk Onderzoek (FWO) Vlaanderen” of Belgium.

\section{Footnotes}

Ethical Approval: Is not applicable.

Transparency Declaration: The authors declare that there is no conflict of interest.

\section{References}

1. Coppola N, Alessio L, Gualdieri L, Pisaturo M, Sagnelli C, Caprio N, et al. Hepatitis B virus, hepatitis $C$ virus and human immunodeficiency virus infection in undocumented migrants and refugees in southern Italy, January 2012 to June 2013. Euro Surveill. 2015;20(35):30009. doi: 10.2807/1560-7917.ES.2015.20.35.30009. [PubMed: 26530499].

2. The Lancet Infectious D. Viral hepatitis: setting sights on the right target. Lancet Infect Dis. 2015;15(1):1. doi: 10.1016/S1473-3099(14)71064-3. [PubMed: 25541157].

3. Blumberg BS, Gerstley BJ, Hungerford DA, London WT, Sutnick AI. A serum antigen (Australia antigen) in Down's syndrome, leukemia, and hepatitis. Ann Intern Med. 1967;66(5):924-31. doi: 10.7326/00034819-66-5-924. [PubMed: 4225883].

4. Blumberg BS. Primary and secondary prevention of liver cancer caused by HBV. Front Biosci (Schol Ed). 2010;2:756-63. doi: 10.2741/s98. [PubMed: 20036981].

5. Bukh J. The history of hepatitis C virus (HCV): Basic research reveals unique features in phylogeny, evolution and the viral life cycle with new perspectives for epidemic control.J Hepatol. 2016;65(1 Suppl):S2S21. doi: 10.1016/j.jhep.2016.07.035. [PubMed: 27641985].

6. Weusten J, van Drimmelen H, Vermeulen M, Lelie N. A mathematical model for estimating residual transmission risk of occult hepatitis B virus infection with different blood safety scenarios. Transfusion. 2017;57(3pt2):841-9. doi: 10.1111/trf.14050. [PubMed: 28244600].

7. Linauts S, Saldanha J, Strong DM. PRISM hepatitis B surface antigen detection of hepatits $B$ virus minipool nucleic acid testing yield samples. Transfusion. 2008;48(7):1376-82. doi: 10.1111/j.15372995.2008.01698.x. [PubMed: 18422847].

8. O'Brien SF, Yi QL, Fan W, Scalia V, Kleinman SH, Vamvakas EC. Current incidence and estimated residual risk of transfusion-transmitted infections in donations made to Canadian Blood Services. Transfusion. 2007;47(2):316-25. doi: 10.1111/j.1537-2995.2007.01108.x. [PubMed: 17302779].

9. Hauser L, Roque-Afonso AM, Beyloune A, Simonet M, Deau Fischer B, Burin des Roziers N, et al. Hepatitis $\mathrm{E}$ transmission by transfusion of Intercept blood system-treated plasma. Blood. 2014;123(5):796-7. doi: 10.1182/blood-2013-09-524348. [PubMed: 24482503].
10. Sobral PM, Barros AE, Gomes AM, do Bonfim CV. Viral inactivation in hemotherapy: systematic review on inactivators with action on nucleic acids. Rev Bras Hematol Hemoter. 2012;34(3):231-5. doi: 10.5581/1516-8484.20120056. [PubMed: 23049426].

11. Sauvage V, Eloit M. Viral metagenomics and blood safety. Transfus Clin Biol. 2016;23(1):28-38. doi: 10.1016/j.tracli.2015.12.002. [PubMed: 26778104].

12. Miri SM, Alavian SM. Epidemiology of hepatitis A virus infections in syria, 2017; war and asylum seekers: A global threat. Iran Red Crescent Med J. 2017;19(11). doi: 10.5812/ircmj.63622.

13. Pourkarim MR, Vergote V, Amini-Bavil-Olyaee S, Sharifi Z, Sijmons S, Lemey P, et al. Molecular characterization of hepatitis B virus (HBV) strains circulating in the northern coast of the Persian Gulf and its comparison with worldwide distribution of HBV subgenotype D1. J Med Virol. 2014;86(5):745-57. doi: 10.1002/jmv.23864. [PubMed: 24532489].

14. The L. Eliminating viral hepatitis: time to match visions with action. Lancet. 2017;390(10108):2121. doi: 10.1016/S0140-6736(17)32856-8. [PubMed: 29143741].

15. Gonzalez R, Echevarria JM, Avellon A, Barea L, Castro E. Acute hepatitis $B$ virus window-period blood donations detected by individualdonation nucleic acid testing: a report on the first two cases found and interdicted in Spain. Transfusion. 2006;46(7):1138-42. doi: 10.1111/j.1537-2995.2006.00863.x. [PubMed: 16836560].

16. Candotti D, Allain JP. Transfusion-transmitted hepatitis B virus infection. J Hepatol. 2009;51(4):798-809. doi: 10.1016/j.jhep.2009.05.020. [PubMed: 19615780].

17. Pourkarim MR, Sharifi Z, Soleimani A, Amini-Bavil-Olyaee S, Elsadek Fakhr A, Sijmons S, et al. Evolutionary analysis of HBV "S" antigen genetic diversity in Iranian blood donors: a nationwide study. J Med Virol. 2014;86(1):144-55. doi: 10.1002/jmv.23798. [PubMed: 24150816].

18. Pourkarim MR, Van Ranst M. Guidelines for the detection of a common source of hepatitis B virus infections. Hepat Mon. 2011;11(10):7835. doi: 10.5812/kowsar.1735143X.773. [PubMed: 22224075].

19. Koppelman MH, Sjerps MC, Reesink HW, Cuypers HT. Evaluation of COBAS AmpliPrep nucleic acid extraction in conjunction with COBAS Ampliscreen HBV DNA, HCV RNA and HIV-1 RNA amplification and detection. Vox Sang. 2005;89(4):193-200. doi: 10.1111/j.14230410.2005.00691.x. [PubMed: 16262751].

20. Amini-Bavil-Olyaee S, Pourkarim MR, Schaefer S, Mahboudi F, Van Ranst M, Adeli A, et al. Single-step real-time PCR to quantify hepatitis B virus and distinguish genotype D from non-D genotypes.J Viral Hepat. 2011;18(4):300-4. doi: 10.1111/j.1365-2893.2010.01308.x. [PubMed: 20367802].

21. Zou S, Caler L, Colombini-Hatch S, Glynn S, Srinivas P. Research on the human virome: where are we and what is next. Microbiome. 2016;4(1):32. doi: 10.1186/s40168-016-0177-y. [PubMed: 27341799].

22. Dwyre DM, Fernando LP, Holland PV. Hepatitis B, hepatitis C and HIV transfusion-transmitted infections in the 21st century. Vox Sang. 2011;100(1):92-8. doi: 10.1111/j.1423-0410.2010.01426.x. [PubMed: 21175659].

23. Stramer SL. Current perspectives in transfusion-transmitted infectious diseases: emerging and re-emerging infections. ISBT Sci Ser. 2014;9(1):30-6. doi: 10.1111/voxs.12070. [PubMed: 25210533].

24. Kohl C, Brinkmann A, Dabrowski PW, Radonic A, Nitsche A, Kurth A. Protocol for metagenomic virus detection in clinical specimens. Emerg Infect Dis. 2015;21(1):48-57. doi: 10.3201/eid2101.140766. [PubMed: 25532973].

25. Li L, Deng X, Mee ET, Collot-Teixeira S, Anderson R, Schepelmann S, et al. Comparing viral metagenomics methods using a highly multiplexed human viral pathogens reagent. J Virol Methods. 2015;213:13946. doi: 10.1016/j.jviromet.2014.12.002. [PubMed: 25497414].

26. Briese T, Kapoor A, Mishra N, Jain K, Kumar A, Jabado OJ, et al. Virome Capture Sequencing Enables Sensitive Viral Diagnosis and Comprehensive Virome Analysis. MBio. 2015;6(5):e01491-15. doi: 10.1128/mBio.01491-15. [PubMed: 26396248]. 
27. Sauvage V, Laperche S, Cheval J, Muth E, Dubois M, Boizeau L, et al. Viral metagenomics applied to blood donors and recipients at high risk for blood-borne infections. Blood Transfus. 2016;14(5):400-7. doi: 10.2450/2016.0160-15. [PubMed: 27136432].

28. Lau P, Cordey S, Brito F, Tirefort D, Petty TJ, Turin L, et al. Metagenomics analysis of red blood cell and fresh-frozen plasma units. Transfusion. 2017;57(7):1787-800. doi:10.1111/trf.14148. [PubMed: 28497550].

29. Furuta RA, Sakamoto H, Kuroishi A, Yasiui K, Matsukura H, Hirayama F. Metagenomic profiling of the viromes of plasma collected from blood donors with elevated serum alanine aminotransferase levels. Transfusion. 2015;55(8):1889-99. doi: 10.1111/trf.13057. [PubMed: 25721073].

30. Kapoor A, Kumar A, Simmonds P, Bhuva N, Singh Chauhan L, Lee B, et al. Virome Analysis of Transfusion Recipients Reveals a Novel Human Virus That Shares Genomic Features with Hepaciviruses and Pegiviruses. MBio. 2015;6(5):e01466-15. doi:10.1128/mBio.01466-15. [PubMed: 26396247].

31. Berg MG, Lee D, Coller K, Frankel M, Aronsohn A, Cheng K, et al. Discovery of a Novel Human Pegivirus in Blood Associated with Hepatitis C Virus Co-Infection. PLoS Pathog. 2015;11(12). e1005325. doi: 10.1371/journal.ppat.1005325. [PubMed: 26658760].

32. Sauvage V, Gomez J, Boizeau L, Laperche S. The potential of viral metagenomics in blood transfusion safety. Transfus Clin Biol. 2017;24(3):218-22. doi: 10.1016/j.tracli.2017.06.018. [PubMed: 28694025].

33. Popgeorgiev N, Colson P, Thuret I, Chiarioni J, Gallian P, Raoult
D, et al. Marseillevirus prevalence in multitransfused patients suggests blood transmission. J Clin Virol. 2013;58(4):722-5. doi: 10.1016/j.jcv.2013.10.001. [PubMed: 24183312].

34. Uch R, Fournier PE, Robert C, Blanc-Tailleur C, Galicher V, Barre R, et al. Divergent Gemycircularvirus in HIV-Positive Blood, France. Emerg Infect Dis. 2015;21(11):2096-8. doi: 10.3201/eid2111.150486. [PubMed: 26488181].

35. Ramamurthy M, Sankar S, Kannangai R, Nandagopal B, Sridharan G. Application of viromics: a new approach to the understanding of viral infections in humans. Virusdisease. 2017;28(4):349-59. doi: 10.1007/s13337-017-0415-3. [PubMed: 29291225].

36. Guinoiseau T, Moreau A, Hohnadel G, Ngo-Giang-Huong N, Brulard C, Vourc'h P, et al. Deep sequencing is an appropriate tool for the selection of unique Hepatitis C virus (HCV) variants after single genomic amplification. PLoS One. 2017;12(3). e0174852. doi: 10.1371/journal.pone.0174852. [PubMed: 28362878].

37. McPhee F, Hernandez D, Zhou N. Effect of minor populations of NS5A and NS5B resistance-associated variants on HCV genotype-3 response to daclatasvir plus sofosbuvir, with or without ribavirin. Antivir Ther 2017;22(3):237-46. doi: 10.3851/IMP3120. [PubMed: 28008868].

38. Ayres A, Yuen L, Jackson KM, Manoharan S, Glass A, Maley M, et al. Short duration of lamivudine for the prevention of hepatitis B virus transmission in pregnancy: lack of potency and selection of resistance mutations. J Viral Hepat. 2014;21(11):809-17. doi: 10.1111/jvh.12212. [PubMed: 24329944]. 